\title{
Bacteriophage Phi X 174
}

National Cancer Institute

\section{Source}

National Cancer Institute. Bacteriophage PhiX 174. NCI Thesaurus. Code C97346.

A bacteriophage that infects E. coli. Its genome is a circular DNA of 5386 bases. 